JACEK DWORZECKI

Wyższa Szkoła Policji w Szczytnie

DOMINIK HRYSZKIEWICZ

Wyższa Szkoła Policji w Szczytnie

\title{
Information management in the police force of the Slovak Republic
}

\section{Introduction}

The citizens of each and every democratic and pro-social state organism are vividly interested in all areas of the functioning of their country, including also the functioning of institutions creating its complex state apparatus. It is no different when it comes to the functioning of Police, the officers of which undertake statutory actions on a daily basis towards ensuring safety and public order. Such interest of public opinion in the above-mentioned group is visible as a constant, increasing trend. Mass media continuously present information referring to practically all areas of functioning of the country to its citizens, therefore, ongoing cooperation with them lies in the best interest of each pro-social institution. In the operations of the Police Corps, contacts with the media have for many years been the priority for this largest Slovak military force. ${ }^{1}$ The Police Corps of the Slovak Republic, as a serving entity to social life, must be at all times prepared for an adequate reaction to often occurring extraordinary situations. In countries with a democratic system, the actions of officers from the force of police prevention are regulated by many legal acts, starting from the Constitution, through ratified international agreements, national acts, and ending with regulations, ordinances and other related provisions.

The most important legal regulation which refers in a specific part (Chapter III, Art. 26) among others to the citizens' right of information is of course

1 J. Dworzecki, M. Ondicová, J. Mlýnek, Stowacy wobec wybranych patologii społecznych, Pszczyna 2013, pp. 120-196. 
the Constitution of the Slovak Republic. ${ }^{2}$ The content of article 26 in point 5 notes that "Organs of public administration and local administration are obliged in a justified method to communicate in an official manner information about its actions". ${ }^{3}$ Furthermore, the main obligation referring to informing public opinion of the actions of the Police Corps is $\S 6$ of the Act no. 301 of the National Council of the Slovak Republic of $24^{\text {th }}$ May 2005 Code of Criminal Procedure. ${ }^{4}$ Within this basic editorial unit of this legal act mandatory nature for entities participating in the proceedings (preparatory, investigation) was indicated as well as for courts (in the course of legal proceedings) in the scope of communicating information to public opinion of all unclassified aspects of criminal processes. For this purpose process organs avail the means of mass media while maintaining provisions stemming from legal regulations and concerning, among others, trade secrecy ${ }^{5}$, bank secrecy ${ }^{6}$, secrecy resulting from the provisions of tax ordinance ${ }^{7}$, and communication and correspondence secrecy. ${ }^{8}$ Judicial bodies ought to pass on to the wider society information in such a way so as not to impact the course of proceedings. The priority of relations is a conceptual reference to the described, commented situation while at the same time maintaining secrecy as to information concerning parties of proceedings, i.e., in terms of private matters, among others, the family environment, place of residence, work, or social contacts. Special protection in public media initiated by Slovak state administration institutions or self-governmental ones covers minors or persons with the status of victim in a criminal trial.

A strict substantive legal act which refers to public information is Act no. 211 of the National Council of the Slovak Republic $17^{\text {th }}$ May 2000 on free access to information. ${ }^{9}$ This act-characterized in subsequent parts of this elaboration regulates conditions, procedures, and scope of free access to public information.

Considering the above provisions, one must underline that the Police Corps of the Slovak Republic, treats contact with the public as an integral element of its actions. Outside the provisions of a legal nature, playing a significant role in social life by this force is a determining factor which initiates constant provision of

${ }^{2}$ Constitution of Slovak Republic of $1^{\text {st }}$ September 1992 (Collection of Acts no. 460 of 1992, pp. 1-23).

3 Art. 26, point 5 of Constitution of Slovak Republic (p. 4).

4 Act no. 301 of the National Council of Slovak Republic of $24^{\text {th }}$ May 2005 - Code of Criminal Proceedings (Collection of Acts no. 301 of 2005, part 130, pp. 3098-3218).

5 Act no. 513 of Federal Assembly of the Czech and Slovak Federal Republic of $5^{\text {th }}$ November 1991 - Commercial Code (Collection of Acts no. 513 of 1991, part 98, pp. 2474-2564).

${ }^{6}$ Act no. 566 of the National Council of the Slovak Republic of $18^{\text {th }}$ November 1992 on Slovak National Bank (Collection of Acts no. 566 of 1992, part 113).

7 Act no. 563 of the National Council of the Slovak Republic of $1^{\text {st }}$ December 2009 on tax statements (tax order) (Collection of Acts no. 563 of 2009, part 193, pp. 4314-4372).

${ }^{8}$ Act no. 122 of the National Council of the Slovak Republic of $30^{\text {th }}$ April 2013 on personal data protection (published in Collection of Acts no. 136 of 2014, part 46, pp. 1054-1080).

9 Act no. 211 of the National Council of the Slovak Republic of $17^{\text {th }}$ May 2000 on free access to information (Collection of Acts no. 211 of 2000, part 92, pp. 2790-2798). 
police supervision directed at citizens. Such a doctrine is not only a reflection of the reliable fulfilment by officers of the legal provisions in place, but also a fulfilment of the public's expectations, constituting at the same time a guarantee of development for society.

Elaboration was devoted to the issue of information management in the realms of the functioning of the Police Corps in the Slovak Republic. Legal and organizational regulations were analysed within the text, which forms the modern doctrine of actions of police officers performing their function as spokesmen in contacts with the media and society.

Binding legal regulations, training materials, and subject Slovak literature, as well as press and media releases and reports have been used in preparation of the text. The text was also enriched by information obtained during conducted interviews with experts dealing with the issue of management and social communication in the Police Corps.

Material which was elaborated within the framework of the project called "Building an IT system supporting communication in the Police and other services subordinated to MIA in the aspect of internal safety", No. DOB-BIO7/03/01/2015, is designated for persons scientifically and professionally involved in the issue of safety management, journalism, and social communication as well as for students at the faculties of: Management, Journalism, Media Sciences, and Internal Safety, as well as for all other readers to whom matters related to management in public service and public safety groups are particularly important.

\section{Act no. 211 of the National Slovak Republic of $17^{\text {th }}$ May 2000 on free access to information}

Act no. 211/2000 on free access to information guarantees citizens in Slovakia the right to obtain public information. This legal act indicates not only the role and importance of media in a democratic state, but also subjects of social communication which participate in the flow of information, among others, press units and spokesmen.

The Act, comprising 23 paragraphs, includes among others, definitions of organs, institutions, state entities, and local authorities as well as legal persons obliged to grant public information at their disposal in the mode and principles specified by this Act. As specified in the provisions of the above-noted legal Act, right to public information is at the disposal of each citizen of the Slovak Republic as well as persons holding citizenship of this country but not remaining on its territory, or even foreigners. Furthermore, legal persons and organizational units without legal personality are also entitled to avail of this right. Provisions of the Act specify the time schedule and scope of granted information and methods of 
informing (active-notification, issuance of publications; passive-granting replies to motions). Text of the discussed legal Act contains also the forms of placing motions and restrictions in access to public information, including issues related to the protection of classified information, personal data protection, trade secrecy protection, and protection of the image of persons. The legislator covered also the procedure of disclosing and publishing information, terms of responding to motions (without undue delay, no later than within eight working days after the receipt of motion), legal remedies, registry of motions, and fees for official actions.

\section{Internal regulations and standards in the scope of disclosing information to media and public opinion, in place in the Ministry of Internal Affairs of the Slovak Republic}

The procedures of disclosing information by organizational units placed within the structures of the Ministry of Internal Affairs are defined by Decree no. 67 of the Minister of Internal Affairs of the Slovak Republic of $29^{\text {th }}$ December 2000 on disclosing information to natural and legal persons. The above regulation is an implementing Act to the Act no. 211/2000. Within art. 2 of the regulations it was noted that entities responsible for elaboration of responses are all organizational units of the ministry, in line with their conceptual nature and in consideration of the content of information included in the motion, whilst answers to the enquiries are posted to the applicant by the entity specified in the regulations as Coordinator of information management. The coordinator is obliged to grant a reply not only in situations of a direct enquiry being submitted to him, but also in case of an enquiry directed to the management of the Ministry of Internal Affairs and another Ministry organizational unit. Act coordinator or conceptually adequate entity entitled to react to the enquiry elaborates an answer in the mode and on the principles of access to public information. The registered motion for information is serviced by the coordinator in a complex manner through granting a reply, elaborating a decision on refusal to grant a reply, or handling the matter in a different, legally correct manner. The coordinator manages the process of granting access to public information, among others, through directing enquiries to appropriate conceptually organizational units of the Ministry, as well as resolving, in the case of the occurrence of a/an internal Ministry dispute in the scope of competencies.

Within the structures of the Ministry of Internal Affairs of the Slovak Republic there are two entities holding the status of Coordinator of information management. The leading coordinator is the Department of Printing, Information, and Social Communication placed in the structure of the Office of the Minister of Internal Affairs. The second supporting entity, also with managerial powers in the scope of servicing 
public enquiries, is the Organizational Department subordinated to the Department of Public Administration of MIA. Organizational departments of the ministry and entities which are subordinated to it elaborate replies to the enquiries of natural and legal persons only in the scope of their obtained competencies. At this point one must note, that public information does not constitute the position taken by the conceptual entity towards the issue of a general country nature, legal opinion, interpretation of legal acts and implementing regulations, report, analysis, prognosis, statement etc. Elaboration of an opinion for a specific case sent to the Ministry of Internal Affairs in the form of a question by natural/legal person is not considered granting of public information.

The regulation also orders organizational units and cells of MIA providing public opinion with materials of the programme, conceptual and strategic nature, draft acts and other legal acts which have been sent for the purpose of intra-resort consultations. Distributed materials which ought to be updated at least once a month, ought to be published on internet websites of the Ministry of Internal Affairs and in the place which enables free, physical access to them. Details of the process of disclosing public information by the ministry including, among others, about the structure of the Ministry of Internal Affairs internet website, are subject to decisions of the General Director of the Office of Minister of Internal Affairs.

Experiences of the Slovak MIA in the scope of disclosing public information show that quite often this Ministry deals with so-called notorious applicants. This normally refers to natural persons who submit their enquiries to the entity of public administration multiple times for granting replies to questions which these applicants had already submitted to the given institution. In such cases the coordinator consults with the conceptual unit the content of an enquiry and if it is found to be the same as the previously-submitted motions, the applicant is informed of the enquiry being devoid of purpose with a citation of the reference number of the registered document which constituted a reaction of a given institution to a previously-submitted enquiry.

\section{Social communication in the Police Corps of the Slovak Republic}

In much simplified terms one may note that there is always an ongoing struggle between the Police and media. Editors need to obtain new stories, facts or information correlated with, among others, police actions at any price and in real time. These expectations are attempted to be met by the Police, however, prior to making its statements public it is obliged to thoroughly research the commented case. The proverb "bury the hatchet" between the mass media and the Police raises the process of mass communication onto a higher level while, at the same time, in parallel 
it optimizes the process of information management in this force. Furthermore, a positive derivative of mutual cooperation is an increase of pluralism in a medial policy, bringing the Police closer to the general public, gaining greater credibility and respect by police officers in the eyes of public opinion and appreciation of the public, which constitutes a solid basis for the long-term success of this institution. It is the thorough and honest media policy conducted by the Police which constitutes an image sine qua non for obtaining the public's approval. Conditioning or arguing over the impact of mass media on modern public opinion is pointless.

Public opinion reacts very sensitively to the increased level of threats and state of uncertainty resulting from crime. The surveys conducted by the Office of Public Opinion Research indicate that in the period of the last four years crime "was promoted" to the first three most serious social problems in Slovakia. This makes activities of the Police Corps being carefully observed by all national (and not only) mass media, newspapers, websites or TV and radio programmes are full of information on the fights of the country's forces against crime. In a survey of public opinion carried out in May 2015, as many as 55\% of respondents indicated that they are interested in the activity of the Police Corps and that they carefully follow its successes and failures and furthermore its participants. Within the scope of interest in the authorization of police officers, the selection process and tasks realized by individual members, the survey also contains information on the profession of police officers, among others divisions and organizational units of the Police Corps. According to those surveyed this type of information should be regularly distributed by the Police Corps public relations office. ${ }^{10}$

The mediator between the force and the media is its spokesman. Many crimes are committed every day, many crisis situations occur as well as events of an extraordinary nature which have a direct impact on the level of safety of Slovakian people. The spokesmen from territorial or conceptual units of the Police Corps inform public opinion of the level of danger and reactions to it made by professional services. Under stressful conditions, often without the necessary technical support, the spokesman must grant information of a serious crime, road accident, or other extraordinary situation, bearing in mind that his or her words will then be cited numerous times by many media. For this reason, precise information must reach the recipients which, furthermore, is not incorrect or misleading and which is legally justifiable. This requires the full professionalism on the part of

10 The survey was carried out within the territory of the country by the Office of Public Opinion Surveys in May 2015 on a group of 1130 respondents. The Office of Public Opinion Surveys is an independent organisational unit functioning by the Statistical Office of the Slovak Republic. Both institutions act on the basis of Act no. 540 of the National Council of the Slovak Republic of $29^{\text {th }}$ November 2001 on state statistics (Collection of Acts no. 540 of 2001, part 215, pp. 5642-5650). The Office which was created on $17^{\text {th }}$ July 1967 (and which was incorporated into the structure of the Statistical Office on $1^{\text {st }}$ June 1976) which organizes and conducts representative testing of public opinion concerning, above all, social-economic issues of the functioning of state. Source: own elaboration based on http://portal.statistics.sk (access: 10.12.2016). 
the officers servicing in the Police department of social communication, the work of which is assessed not only by the editors representing various media, but also the public-the readers, listeners, and viewers.

A Police spokesman plays a key role in shaping positive relations between the represented force and the media through performing two basic functions:

1. Ensuring adequate information flow between force policymakers and mass media and promoting action of the Police Corps (striving for the most unbiased and positive information);

2. Protecting the force against media, through adequate and well-thought out and restrained reaction, especially in cases of conceptual misunderstandings, scandals, or issues related to classified information protection.

Police officers who perform the function of spokesmen in organizational units of the Police Corps of the Slovak Republic deal with all matters related to the services provided to the mass media. They ensure coordinated and homogeneous transfer of information to the media, regulating their volume and fastness of flow. For this reason, police spokesmen must participate in all important decisions and actions of the organization, since they are most frequently the first "point of contact" for the information coming and going to and from the individual entities and organizational departments of the Corps. A poorly informed spokesman is in practice a flaw of an organization, thus, a large emphasis is placed on mutual exchange of information also inside the force itself. Press briefings with the participation of spokesmen from other organizational entities of the Police Corps are quite frequent. Police spokesmen also elaborate printed materials for the media, reply in an electronic form, among others, using generally available internet messengers, stage events as well as organize press conferences, edit written positions before external enquiries and written questions, ensuring the flow of information between the force and other entities of state administration and local administration.

Organizational departments of the Police Corps which are located in central units as well as field branches which conduct the majority of tasks in the scope of social communication include:

1. At the central level, within the organizational structure of the Presidium of the Police Corps:

a) Office of International Police Cooperation;

b) Department of Social Communication and Prevention of the Office of Police Corps President;

2. At the province level, within the organizational structure of the Province Headquarters of the Police Corps:

a) Department of Social Communication and Prevention;

3. At the poviat level, within the organizational structure of the Poviat Headquarters of the Police Corps:

a) officer of the Department of Prevention, who is entrusted with the function of non-permanent unit spokesman. 
Office of International Police Cooperation was launched in the structures of

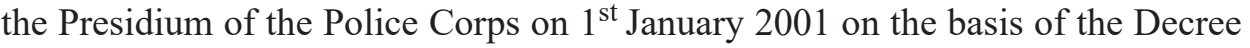
of the Minister of Internal Affairs no. 66/2000. Currently this organizational department of the Presidium is formed by:

1. Department of International Police Cooperation;

2. National Office SIRENE;

3. National Office INTERPOL;

4. National Office EUROPOL;

5. Department for liaisons officers and peace missions.

The task of the Office currently headed by the director, Colonel Jaroslav Palov, is performance of the function of national coordinator on international cooperation and all areas of activity of the Police Corps of the Slovak Republic related to it. ${ }^{11}$ The Department of Social Communication and Prevention located within the structure of the Office of Police Corps President, which is represented by three spokesmen, that is Major Michal Slivka, Major Denisa Baloghová and Captain Martin Wäldl ${ }^{12}$, deals with:

1. Creating and implementing Police Corps strategy and coordinating actions undertaken in its framework;

2. Current service of the online information portal;

3. Ongoing organization of press conferences and briefings with the participation of representatives of the mass media;

4. Elaboration and service of press conferences for the President of the Police Corps with journalists from Slovakia and abroad;

5. Organization of group theme trips with participation of mass media representatives to central and off-site units of the Police Corps;

6. Gathering, analysis and assessment of national and foreign media releases about activities of the Police Corps;

7. Replying or coordinating replies (based on separate regulations) to the enquiries submitted by institutions and external entities in the scope falling under the domain of the Presidium of the Police Corps;

8. Consultation and supervision over the Department of Social Communication and Prevention in the Province Offices of the Police Corps;

9. Creating on behalf of MIA the concept of a general state Strategy of Crime Prevention and Countering Anti-social Behaviour;

11 More information on the Office of International Police Cooperation of the Presidium of the Police Corps of the Slovak Republic may be viewed in: J. Dworzecki, "Korpus Policji Republiki Słowackiej. Organizacja i funkcjonowanie. Część I”, Kwartalnik Kadry Kierowniczej Policja, no 2, pp. 75-92.

12 Source: interview of J. Dworzecki from 08.12.2016 with dr hab. Lubošem Wäldl (Col. rez.), manager of the Chair of Civil Law at the Police Corps Academy in Bratislava, who until 2008 worked for the Office of the Police Corps President. L'. Wäldl is the father of senior lieutenant Martin Wäldl, performing currently the function of spokesman of the President of the Police Corps of the Slovak Republic. 
10. Coordination of actions taken by departments of the Ministry of Internal Affairs and organizational departments of the Presidium of the Police Corps in the scope of initiatives concerning crime prevention;

11. Elaboration of materials used as the official position, opinion, or presentation by the President of the Police Corps in the scope of crime prevention;

12. Website administration of under the supervision of the Presidium of the Police Corps.

A website with its content is in fact the first reliable source of information about the activities of each institution. It is no different in the case of the Police Corps of the Slovak Republic. This media is used both by mass media but also by members of the public. Thanks to access to a reliable source of information which is regularly edited and updated, Slovakian society has the possibility, among others, to verify the distributed information i.e., by means of internet messengers, which are not at all times reliable. This is of great importance in case of occurrence of many extraordinary events or crisis situations. The role of the portal is of course to create a positive image of the force, fostering proper relations with the public as well as fulfilling the mission by the Corps of educating society, among others, in the scope of crime prevention or minimizing victimization factors.

A key difference i.e., in terms of Polish police regarding social communication, is the fact that the Police Corps in the Slovak Republic has only one internet portal concerning the activities of the force. This portal is placed on MIA servers as a sub-website of the Ministry and includes data identifying the organizational departments of the Presidium of the Police Corps in Bratislava as well as all field units located within the territory of Slovakia. Any person who uses the portal has a chance to identify, among others, the force managerial team, management members of individual departmentss of the Presidium of the Police Corps as well as managerial staff of field units (Province departments, poviat departments) and managerial staff of individual types of services (prevention, crime, road traffic) in these units. Furthermore, the portal contains current information from the life of individual units and initiatives undertaken by the Corps at the central level. At this point one must add that the range of tasks undertaken by officers of the Police Corps is very wide, since outside strictly "police-related work" they also deal with operations of a control-protection character, among others, along external borders and within the area of international airports of the Slovak Republic (they perform tasks which in Poland are carried out by the Border Guards), protect constitutional state officials and selected objects of public administration and national and foreign diplomatic facilities (in Poland these tasks are carried out by the Government Protection Office). ${ }^{13}$ Patrolling-intervention actions and protective actions also cover rail infrastructure, which in our country is the domain of the Rail Protection Guard. Thus, stemming from the above observations, the statutory

13 Act no. 171 of the National Council of the Slovak Republic of $6^{\text {th }}$ July 1993 on Police Corps (Collection of Acts of 1993, part 46, pp. 770-784 as amended). 
tasks assigned to the Police Corps require not only huge flexibility in reactivity from this force but also impose a far-reaching transparency in presenting its activities to the public. The only instrument used for such remittance is the generally available portal designated for the organization and functioning of the Police Corps in the Slovak Republic.

With regards to conceptual tasks which are carried out at the provincial level, individual Departments of Social Communication and Prevention must be indicated, with their remit not differing significantly from the actions undertaken by an analogous department of the Presidium of the Police Corps. Of course, these departments do not conduct any tasks related to the supervision and coordination of social communication and crime prevention at a central level, but these types of tasks are conducted on a conceptually subordinated area in the scope subordinated to the Department of Provincial Police Corps and they service the management of units at this level. The core of each press team located within the structure of the discussed departments is formed by a minimum of two officers fulfilling the function of spokesman.

Both the current press actions and initiatives targeted at creating the image of the Police Corps undertaken by press departments of organizational entities of the force are based, among others, on press law, police regulations as well as governmental and resort strategies of actions and generally binding in this scope standards and good practices.

\subsection{Entities authorized for cooperation with mass media and granting information on behalf of the Police Corps of the Slovak Republic}

Mattersof a uniform nature of relations and contacts with the mass media have been characterized in the Ordinance of the Minister of Internal Affairs of $10^{\text {th }}$ May 2004 on granting information to the mass media. ${ }^{14}$ The above regulation applies a group of authorized personnel and principles of granting information to representatives of the mass media. The concept of information contained within the ordinance covers statements, reports, announcements, bulletins, and appeals which concern safety and public order, fighting crime as well as other areas of activity of the ministry and institutions subordinated to it. Provisions of the hereby Act do not decide about matters related to the protection of classified information and personal data protection, thus other provisions (previously cited) are used in case of these matters.

In accordance with art. 2 of the described Ordinance of MIA, persons authorized to have contacts with the media are: Minister of Internal Affairs,

14 Ordinance of the Minister of Internal Affairs of $10^{\text {th }}$ May 2004 on granting information to the mass media (Official Journal of MIA of 2004, part 38, p. 2-5). 
Undersecretary of State, Press Spokesman of MIA, department director of MIA appropriate for matters related to social communication, President of the Police Corps and his two deputies, Provincial Commandant of the Police Corps and his deputies, Poviat Commandant of the Police Corps and his deputies, spokesman of the Presidium of the Police Corps and his deputies, police officers from the investigation department and other authorized officers, Director of the Office of Protection of Constitutional State Officials and Diplomatic Missions of MIA, President of State Rescue-Firefighters and his deputy and spokesman of this force, the Rector of the Police Corps Academy in Bratislava and other officers of the Police Corps, State Rescue-Firefighters as well as employees of the ministerial unit on matters of social communication authorized (including verbally) based on separate provisions. Directors of MIA departments and their deputies who were not mentioned in the ordinance, only in extraordinary, justified cases (i.e., If competent persons are unable to pass on the information) are entitled to contact the media. They pass on the information limited to the scope of their own, conceptual competencies. In rare cases the Commandants of the Poviat Police Corps may assign to their subordinate an authorization to contact the media in the scope referring to a short, specific message. The officer who acts on their behalf cannot reply to questions. A Police officer who undertakes the investigation work may speak only in the scope of matters based on regulations of the criminal codes of proceedings. Prior to speaking they are obliged to inform the spokesman of MIA or authorized persons from the ministerial department on social communication of their intentions.

All messages and data contained therein are previously analysed in terms of preventing any information which might impact the further course of conducted procedures being leaked to the public . An irrespective ban concerns matters covered by state secrecy and via ordinance-not to be disclosed. Full information in such a case is granted only after cessation of factual obstacles or post consultation with investigation leaders and obtaining their consent for publishing previously protected aspects of the case.

The duty operational officer in the country who performs the function in the central position of commanding the Presidium of the Police Corps is obliged to inform the spokesman of MIA (or persons in the ministry who are authorized), spokesman of the Presidium of the Police Corps (or persons within the Presidium who are authorized) about occurrences within the territory of the country of an event of extraordinary character of which the public should be informed without delay. Furthermore, the duty officer informs the spokesmen of events which are very likely to be of interest both to the public and the mass media. Similar tasks in the scope of information flow, in consideration of the field structure of the Police Corps, are made also by duty officers performing the function in operational positions of both Provincial and poviat departments. They pass on information to local police press spokesmen or operational officers. 
Here, one must indicate that sending information or office documents in electronic form takes place in all departments and organizational units of the Corps with the use of an Intranet network. Technological support in this scope is granted by the Department of Police Service of Databases of Presidium of the Police Corps, whilst escorting and protection of special post on the main, internal provincial and local courier routes takes place with the use of forces and resources located at the disposal of the prevention services appropriate territorially to the organizational units of the Police Corps.

\section{Conclusion}

The key factors which impact social assessment of each force of police prevention include public trust for the operational group and officers providing service within its framework. Without social trust one cannot speak of evolution and further development of the Police. The public's support for actions described in the hereby elaboration, the largest Slovak military formation has been constantly growing for several years and one of the key accelerators is appropriate conducted by authorized police departments' process of social communication and information management.

\section{Bibliography}

Dworzecki, J. 2014. “Korpus Policji Republiki Słowackiej. Organizacja i funkcjonowanie. Część I”. Kwartalnik Kadry Kierowniczej Policja, no 2.

Dworzecki, J., Ondicová, M., Mlýnek, J. 2013. Słowacy wobec wybranych patologii społecznych. Pszczyna: Oficyna Drukarska Z. Spyra.

\section{Legal Acts}

Constitution of the Slovak Republic of $1^{\text {st }}$ September 1992 (Collection of Acts no. 460 of 1992 , pp. 1-23).

Act no. 513 of the Federal Assembly of the Czech and Slovak Federal Republic of $5^{\text {th }}$ November 1991-Commercial Code (Collection of Acts no. 513 of 1991, part 98, pp. 2474-2564).

Act no. 566 of the Federal Assembly of the Czech and Slovak Federal Republic of $18^{\text {th }}$ November 1992 on the Slovak National Bank (Collection of Acts no. 566 of 1992, part 113).

Act no. 171 of the National Council of the Slovak Republic of $6^{\text {th }}$ July 1993 on the Police Corps (Collection of Acts of 1993, part 46, pp. 770-784 as amended).

Act no. 211 of the National Council of the Slovak Republic of $17^{\text {th }}$ May 2000 on free access to information (Collection of Acts no. 211 of 2000, part 92, pp. 2790-2798).

Act no. 540 of the National Council of the Slovak Republic of $29^{\text {th }}$ November 2001 on state statistics (Collection of Acts no. 540 of 2001, part 215, pp. 5642-5650). 
Act no. 301 of the National Council of the Slovak Republic of $24^{\text {th }}$ May 2005-Code of Criminal Proceedings (Collection of Acts no. 301 of 2005, part 130, pp. 3098-3218).

Act no. 563 of the National Council of the Slovak Republic of $1^{\text {st }}$ December 2009 on tax statements (tax order) (Collection of Acts no. 563 of 2009, part 193, pp. 4314-4372).

Act no. 122 of the National Council of the Slovak Republic of $30^{\text {th }}$ April 2013 on personal data protection (published in Collection of Acts no. 136 of 2014, part 46, pp. 1054-1080).

Ordinance of the Minister of Internal Affairs of $10^{\text {th }}$ May 2004 on granting information to mass media (Official Journal of MIA of 2004, part 38, pp. 2-5).

\section{Other sources}

http://portal.statistics.sk.

Interview with dr hab L'ubošem Wäldl (obtained on: 8.12.2016).

INFORMATION MANAGEMENT IN THE POLICE FORCE OF THE SLOVAK REPUBLIC

Summary

The article presents the process of information management within the realms of the functioning of the Police Corps in the Slovak Republic. The described solutions concern broadly understood social communication, which is the participation of press departments of this largest military force responsible for safety and public order in our southern neighbour. Within the article both organizational and doctrinal solutions were presented in the scope of contacts with media, information flow between individual departments, and organizational units of the Police Corps.

Keywords: the Slovak Republic, Police Corps, information management.

Jacek Dworzecki

j.dworzecki@wspol.edu.pl

Dominik Hryszkiewicz

d.hryszkiewicz@wspol.edu.pl 